\title{
Komposisi Nutrien Larva Black Soldier Fy (Hemetia illucent) dengan Media Tumbuh, Suhu dan Waktu Pengeringan yang Berbeda
}

\section{(Nutrient Composition of Black Soldier Ry (Hemetia illucent) Lanae Using Different Growth Media, Temperature and Drying Time}

\author{
Purnamasari L ${ }^{1}$, Sucipto $\mathrm{I}^{2}$, Muhlison $\mathrm{W}^{2}$, Pratiwi $\mathrm{N}^{3}$ \\ ${ }^{1}$ Program Studi Peternakan, Fakultas Pertanian, Universitas Jember \\ ${ }^{2}$ Program Studi Agroteknologi, Fakultas Pertanian, Universitas Jember \\ ${ }^{3}$ Balai Penelitian Ternak, Ciawi-Bogor \\ listyashachan@gmail.com
}

\begin{abstract}
Flies Hermetia illucens or better known as black soldier fly (BSF) or black army flies is a strong candidate for a source of protein that has high prices. This BSF is potential to be used as a candidate for fish meal subtitute which is used as the main component of protein sources in making fish feed or animal feed. BSF is abundant in nature and can also be cultivated with the help of organic waste. This study examines the nutrient content of BSF larvae with various types of waste used in its maintenance and from several variations in the temperature of drying and drying time. The wastes that used to grow the BSF larvae were cassava peel, fruit pulp, tofu waste and food scraps. The variables measured were the nutrient content of the dried 15 day-old larvae. The results showed that BSF larvae can be dried with a temperature range of $55-75^{\circ} \mathrm{C}$ with duration of $18-24$ hours. The protein nutrient content is roughly between $41.99-51.49 \%$. From this study it can be concluded that the highest protein content of BSF larvae when grew in tofu waste and dried at $55^{\circ} \mathrm{C}$ for 24 hours.
\end{abstract}

Key words: Black soldier fly, organic waste, protein source, maggot

\begin{abstract}
ABSTRAK
Lalat Hermetia illucens atau lebih dikenal dengan istilah black soldier fly (BSF) atau lalat tentara hitam.merupakan kandidat kuat sebagai pengganti sumber protein yang selama ini memiliki harga tinggi. Potensi BSF ini dapat dijadikan sebagai kandidat pengganti tepung ikan yang selama ini digunakan sebagai komponen utama sumber protein dalam pembuatan pakan ikan maupun pakan unggas. Ketersediaan lalat BSF melimpah di alam dan juga dapat dibudidayakan secara massal dengan memanfaatkan limbah organik sehingga dapat juga mengatasi permasalahan lingkungan. Penelitian ini mengkaji mengenai kandungan nutrien dari larva BSF dengan berbagai macam limbah yang digunakan dalam pemeliharaannya serta dari beberapa suhu pengeringan dan waktu pengeringan. Limbah yang digunakan yaitu limbah kulit singkong, limbah buah, ampas tahu dan sisa makanan. Parameter yang diukur yaitu kandungan nutrien hasil pengeringan larva umur 15 hari. Hasil penelitian menunjukkan bahwa larva BSF dapat dikeringkan dengan rentang suhu $55-75^{\circ} \mathrm{C}$ dengan lama waktu 18-24 jam. Kandungan nutrien utamanya protein kasar berkisar antara 41,99-51,49\%. Dari penelitian ini dapat disimpulkan bahwa kandungan protein tertinggi dalam larva BSF bila ditumbuhkan pada ampas tahu dan dikeringkan pada suhu $55^{\circ} \mathrm{C}$ selama 24 jam.
\end{abstract}

Kata kunci: Lalat tentara hitam, limbah organik, sumber protein, maggot 


\section{PENDAHULUAN}

Keberhasilan dalam budidaya pakan ternak salah satunya ditentukan oleh faktor pakan yaitu $60-70 \%$ dari total biaya pemeliharaan. Pakan sumber protein merupakan nutrien utama dalam pertumbuhan dan perkembangan ternak dan harganya cenderung mahal. Insekta merupakan salah satu kandidat sumber protein pakan yang ekonomis, ramah lingkungan dan mudah diproduksi secara masal (Van Huis 2013). Sumber protein berbasis insekta tidak bersaing dengan manusia dan insekta mampu mengurai limbah organik yang berpotensi mencemari lingkungan.

Permasalahan akan limbah di Indonesia menjadi sebuah permasalahan yang tidak pernah ada solusinya. Perkembangan jumlah limbah di Indonesia tiap tahun bukan malah menurun justru semakin membludak jumlahnya. Berdasarkan target Millenium Development Goals (MDGs) pada tahun 2015 tingkat pelayanan persampahan ditargetkan mencapai $80 \%$. Namun di Indonesia berdasarkan data BPS hanya 41,28\% sampah yang dibuang ke tempat pembuangan sampah (TPA), dibakar sebesar 35,59\%, dibuang ke sungai $14,01 \%$, dikubur sebesar $7,79 \%$ dan hanya $1,15 \%$ yang diolah sebagai kompos. Sampah organik menempati persentase tingginya tingkat jumlah sampah di Indonesia dibandingkan dengan tingkat jumlah sampah dari tipe sampah lainnya seperti sampah plastik, kertas, tekstil, karet, metal, kaca, dan yang lainnya (Kardono 2007). Proses daur ulang pada limbah organik biasanya menggunakan bantuan mikroba dan bantuan agen lain seperti dari golongan serangga dan vermiform. Black soldier fly (BSF), Hermetia illucens merupakan salah satu jenis serangga yang larvanya mampu membiokonversi limbah organik.

Wilayah indonesia sangat berpotensi dilakukan pengembangan lalat BSF karena didukung dari kondisi iklim dan ketersediaan bahan baku limbah organik sebagai media tumbuh larva BSF. Larva BSF memiliki potensi sebagai sumber protein ternak yang murah dan mudah dalam budidayanya serta membantu mengurangi pencemaran lingkungan dari limbah-limbah organik. Keberhasilan produksi dan kualitas dari larva BSF salah satunya ditentukan dari media pertumbuhan dan proses pengeringan sebelum digunakan sebagai bahan baku pakan. Penelitian ini menganalisis kandungan nutrien dari larva BSF dengan berbagai macam limbah yang digunakan dalam pemeliharaannya dan dari beberapa suhu pengeringan serta waktu pengeringan.

\section{MATERI DAN METODE}

Serangga yang digunakan dalam penelitian ini adalah larva Hermetia illucens (Diptera: Stratiomyidae). Serangga $H$. illucens diperoleh dari alam dengan cara memancing $H$. illucens untuk bertelur pada eggies yang telah disediakan. Telur yang diperoleh kemudian di inkubasi dan diletakkan pada wadah plastik penetasan (20 cm x 12 $\mathrm{cm}$ x $7 \mathrm{~cm}$ ) dengan tutup berkain kasa yang di dalamnya diberikan media pakan berupa pur ayam dengan kadar air 75\%, setelah tiga hari telur akan menetas menjadi larva.

Larva $H$. illucens yang berumur lima hari kemudian dipindahkan pada media pembesaran (40 cm x $20 \mathrm{~cm}$ x $15 \mathrm{~cm}$ ) dan diisi dengan media pakan berupa pur ayam + ampas tahu + dedak jagung dengan kadar air 50\%. Waktu pembesaran larva $H$. illucens selama 30 hari, setiap 5 hari diberikan media pakan dengan kadar air bertingkat yaitu 50 , 60, 75, 80, 85, dan 90\%. Saat memasuki fase pupa, larva $H$. illucens akan pindah ke tempat yang kering yang telah disediakan, larva yang masuk menjadi fase pupa akan ditempatkan pada ruang gelap selama 5 hari, setelah 5 hari pupa akan menjadi imago $H$. illucens, pada fase ini ditempatkan pada wadah kawin dan bertelur yang didalamnya telah 
disediakan media attract peneluran, eggies dan tempat air. Imago yang telah kawin akan tertarik untuk bertelur pada eggies. Telur yang diperoleh akan dipanen dan diletakkan pada wadah penetasn telur selama lima hari. Larva $H$. illucens yang berumur lima hari kemudian dipanen dan siap untuk dijadikan serangga uji.

Alat yang digunakan dalam penelitian ini yaitu wadah/bak pembesaran larva, oven pengering, ayakan/saringan, dan timbangan. Perlakuan pertama yang digunakan yaitu media pertumbuhan berupa limbah organik yaitu limbah kulit singkong, limbah buah, ampas tahu dan sisa makanan. Larva BSF umur 5 hari ditimbang masing-masing 15 gram kemudian dimasukkan ke dalam media pembesaran berupa limbah-limbah organik sebanyak 15 kg kemudian dibesarkan selama 15 hari. Setelah 15 hari larva BSF dipanen kemudian dikeringkan. Setelah pengeringan dilakukan pengujian proksimat larva dari berbagai media pembesaran. Perlakuan selanjutnya yaitu suhu dan lama pengeringan. Penetapan berat awal dilakukan sebelum pengeringan dan penetapan berat akhir dilakukan setelah pengeringan dengan menggunakan oven modifikasi suhu dan waktu. Setelah diberlakukan pengeringan dan pengukuran bobot, tidak diukur kadar air. Parameter yang diukur yaitu kandungan nutrien hasil pengeringan larva umur 15 hari.

\section{HASIL DAN PEMBAHASAN}

Bahan organik merupakan media tumbuh dan berkembangnya larva BSF. Menurut Mangunwardoyo et al. (2011), larva BSF mampu hidup dalam berbagai media karena mampu hidup dalam rentang $\mathrm{pH}$ yang luas. Larva BSF yang berasal dari alam juga memiliki performa tumbuh yang lebih baik dibandingkan yang dibudidayakan di dalam laboratorium (Tomberlin et al. 2002). Kualitas dan kuantitas media pertumbuhan tidak berpengaruh terhadap bobot larva BSF (Myers et al. 2008) namun berpengaruh terhadap rasio menetas lalat jantan dan betina. Lalat jantan akan lebih banyak menetas pada media pembesaran yang jumlahnya terbatas (Zarkani \& Miswati 2012).

Komposisi nutrien larva BSF secara umum dapat dilihat pada tabel 1. Pengeringan larva umur 15 hari pada tahap ini dilakukan dengan bantuan sinar matahari selama 4 hari. Berbagai macam limbah organik yang digunakan pada proses pembesaran larva menghasilkan kandungan protein yang cukup tinggi yaitu rentang 42,80-48,61\% dengan kandungan lemak mencapai 20,09-28,89\%. Kandungan nutrien tersebut sangat berpotensi digunakan sebagai sumber protein pakan.

Tabel 1. Hasil analisa proksimat larva BSF dari berbagai macam limbah

\begin{tabular}{lcccccc}
\hline \hline Perlakuan media & BK (\%) & Abu (\%) & PK (\%) & SK (\%) & LK (\%) & Beta-N (\%) \\
\hline Kulit singkong & 97,05 & 7,69 & 44,32 & 9,23 & 28,89 & 6,92 \\
Limbah buah & 96,69 & 9,01 & 46,70 & 13,00 & 21,16 & 6,82 \\
Ampas tahu & 96,49 & 8,34 & 48,61 & 19,08 & 20,09 & 0,37 \\
Sisa makanan & 97,93 & 10,36 & 42,80 & 22,03 & 22,54 & 0,20 \\
\hline BK = Bahan kering & & & & & & \\
SK = Serat kasar & & & & & \\
PK = Protein kasar & & & & & \\
LK = Lemak kasar & & & & &
\end{tabular}


Komposisi nutrien utama dalam pakan ternak utamanya unggas adalah protein. Sedangkan lemak dan serat kasar merupakan nutrien yang harus dibatasi. Tujuan utama produksi pakan dengan menggunakan larva maggot BSF adalah sebagai sumber protein pakan. Nilai protein tertinggi didapatkan dalam larva yang dikembangbiakan dalam media ampas tahu. Berdasar media pertumbuhannya, ampas tahu memiliki kandungan nutrien utamanya protein paling tinggi yaitu 23,5-39,2\% (Tribina 2012) sedangkan kulit singkong 4,93-5,77\% (Siburian 2019), untuk limbah buah 23,87\% (Utama \& Mulyanto 2009) dan limbah sisa makanan. Kandungan protein kasar yang tinggi dari larva 15 hari tidak semuanya terdiri dari protein murni tetapi juga ada kontribusi chitin yang sudah terbentuk menjelang larva menjadi pupa, yang tidak dapat dicerna oleh ternak unggas (Sprangher et al. 2017; Wardhana 2016).

Kadar abu menunjukkan bahan non-organik atau residu yang dihasilkan pada proses pembakaran bahan non organik yaitu larva maggot BSF berkisar antara 7,69-10,36. Kadar abu mengindikasikan juga adanya kandungan garam, mineral atau senyawa anorganik dalam bentuk oksida dalam bahan pakan (Winarno 1997). Tingginya kadar abu dan serat kasar pada larva BSF yang dihasilkan sesuai dengan tingginya kadar abu dari media pertumbuhannya. Kadar abu kulit singkong 4,5-6,6\% dan serat kasar 9,3-10,9\% (Wikanastri et al. 2012). Kadar abu ampas tahu yaitu 0,19\% sedangkan serat kasarnya yaitu 24,03\% (Mulia et al. 2015). Tingginya kadar abu akan berbanding lurus dengan tingginya serat kasar sehingga dimungkinkan kecernaan maggot yang mengandung kadar abu dan serat kasar yang tinggi lebih rendah.

Proses pengeringan larva dengan suhu tinggi dapat menyebabkan perubahan nilai nutrien utamanya protein karena mengalami denaturasi. Beberapa suhu dan waktu yang berbeda telah diujikan untuk mengetahui perbedaan kandungan nutrien dari pakan setelah mengalami pengeringan. Metode pengeringan dilakukan dengan menggunakan oven buatan (still oven) dengan pemanfaatan panas dari lampu dan diatur suhunya dengan menggunakan termostat. Nilai protein kasar (PK) pada Tabel 2. dihitung berdasarkan bahan kering sampel yang dikirim ke laboratorium. Tabel 2 merupakan hasil uji kandungan protein pada larva kering.

Tabel 2. Hasil uji protein kasar larva BSF dari beberapa metode pengeringan

\begin{tabular}{|c|c|}
\hline Metode pengeringan & PK (\%) \\
\hline P1W1 (suhu 55, 24 jam) & 50,65 \\
\hline $\mathrm{P} 1 \mathrm{~W} 2$ (suhu $55^{\circ} \mathrm{C}, 36$ jam) & 49,86 \\
\hline $\mathrm{P} 2 \mathrm{~W} 1$ (suhu $65^{\circ} \mathrm{C}, 24$ jam) & 41,99 \\
\hline $\mathrm{P} 2 \mathrm{~W} 2$ (suhu $65^{\circ} \mathrm{C}, 36$ jam) & 50,21 \\
\hline P3W1 (suhu $75^{\circ} \mathrm{C}, 24$ jam) & 48,35 \\
\hline P3W2 (suhu $75^{\circ} \mathrm{C}, 36$ jam) & 51,49 \\
\hline Ulat hongkong & 44,98 \\
\hline
\end{tabular}

$\mathrm{PK}=$ Protein kasar, $\mathrm{P}=$ Suhu pengeringan dan $\mathrm{W}=\mathrm{Waktu}$ pengeringan

Hasil uji menunjukkan bahwa perlakuan suhu dengan rentang $55-75^{\circ} \mathrm{C}$ dalam waktu 24-36 jam tidak merubah kadar protein larva BSF secara signifikan sehingga dapat dikatakan bahwa rentang suhu dan lama waktu terebut ideal digunakan dalam proses pengeringan larva BSF. Penyusutan yang terjadi selama pengeringan (Tabel 3) rata-rata 
mencapai 63,05\% sehingga rendemen larva BSF kering dari bobot segar yaitu sebesar $36,95 \%$.

Tabel 3. Penyusutan berat dari beberapa metode pengeringan larva black soldier fly

\begin{tabular}{lccc}
\hline \hline Metode pengeringan & Berat awal (gram) & Berat akhir (gram) & Penyusutan (\%) \\
\hline suhu $55^{\circ} \mathrm{C}, 24$ jam & 150 & 64 & 57,33 \\
suhu $55^{\circ} \mathrm{C}, 36$ jam & 150 & 55 & 63,33 \\
suhu $65^{\circ} \mathrm{C}, 24$ jam & 150 & 58 & 62,33 \\
suhu $65^{\circ} \mathrm{C}, 36$ jam & 150 & 52 & 65,33 \\
suhu $75^{\circ} \mathrm{C}, 24$ jam & 150 & 55 & 63,33 \\
suhu $75^{\circ} \mathrm{C}, 36$ jam & 150 & 50 & 66,66 \\
\hline Rata-rata & & & 63,05 \\
\hline
\end{tabular}

Dilihat dari Tabel 3, maka penyusutan terbesar adalah pada suhu $75^{\circ} \mathrm{C}$ selama 36 jam sedangkan penyusutan terkecil 57,33\%. Bila dihitung jumlah protein kasar tertinggi yang diperoleh dari larva kering adalah pada pengeringan $55^{\circ} \mathrm{C}$ selama 24 jam yaitu $64 \mathrm{x}$ $50,65 / 100=32,42$ gram atau 506,5 g/kg larva kering.

\section{KESIMPULAN}

Kesimpulan dari penelitian ini yaitu media pertumbuhan larva, suhu dan waktu pengeringan yang berbeda menghasilkan kandungan nutrien yang berbeda. Kandungan protein tertinggi dalam larva BSF bila ditumbuhkan pada media ampas tahu dan dikeringkan pada suhu $55^{\circ} \mathrm{C}$ selama 24 jam.

\section{UCAPAN TERIMA KASIH}

Ucapan terimakasih penulis ucapkan kepada Lembaga Penelitian dan Pengabdian Kepada Masyarakat (LP2M) yang telah memberikan bantuan dana melalui hibah internal kelompok riset (keris) sumber dana internal BOPTN tahun anggaran 2019.

\section{DAFTAR PUSTAKA}

Kardono K. 2007. Integrated solid waste management in Indonesia. Proceeding of International Symposium on EcoTopia Science. hlm. 629-633.

Mangunwardoyo W, Aulia, Hem S. 2011. Penggunaan bungkil inti kelapa sawit hasil biokonversi sebagai substrat pertumbuhan larva Hermetia illucens L. (maggot). Biota. 16:166-172.

Mulia SM, Yulyanti E, Maryanto H, Purbomartono C. 2015. Peningkatan kualitas ampas tahu sebagai bahan baku pakan ikan dengan fermentasi Rhizopus oligosporus. Sainteks 12:1020.

Myers HM, Tomberlin JK, Lambert BD, Kattes D. 2008. Development of black soldier fly (Diptera: Stratiomyidae) larvae fed dairy manure. Environ Entomol. 37:11-15.

Pangestu W, Prasetya A, Cahyono RB. 2017. Pengolahan limbah kulit pisang dan nangka muda menggunakan larva black soldier fly (Hermetia illucens). Simposium nasional RAPI XVI. hlm. 97-101. 
Siburian IS. 2019. Pengaruh fermentasi kulit singkong (Manihot esculenta crantz) dengan mikroorganisme lokal (MOL) sebagai pakan terhadap kandungan nutrisi dan antinutrisi asam sianida [Skripsi]. [Medan (Indonesia)]: Universitas Sumatera Utara.

Suciati R, Faruq R. 2017. Efektifitas media pertumbuhan maggots Hermetia illucens (lalat tentara hitam) sebagai solusi pemanfaatan sampah organik. J Bio Pend Bio. 1:8-13.

Tomberlin JK, Sheppard DC. 2002. Factors influencing mating and oviposition of Black Soldier Flies (Diptera: Stratiomyidae) in a colony. J Entomol Sci. 37:345-352.

Tribina A. 2012. Pemanfaatan silase kering ampas tahu untuk pakan ikan nila merah (Oreochromis niloticus). J Teknologi Perikanan Kelautan. 3:27-33.

Utama CS, Mulyanto A. 2009. Potensi limbah pasar sayur menjadi starter fermentasi. J Kesehatan. 2:6-13.

Van Huis A. 2013. Potential of insects as food and feed in assuring food security. Ann Rev Entomol. 58:563-583.

Wardhana AH. 2016. Black soldier fly (Hermetia illucens) sebagai sumber protein alternatif untuk pakan ternak. Wartazoa. 26:69-78.

Zarkani A, Miswati. 2012. Teknik budidaya larva Hermetia illucens (Linnaeus) (Diptera: Stratiomyidae) sebagai sumber protein pakan ternak melalui biokonversi limbah loading ramp dari pabrik CPO. J Entomol Indonesia. 9:49-56.

Wikanastri H, Uta CS, Suyanto A. 2012. Aplikasi proses fermentasi kulit singkong menggunakan starter asal limbah kubis dan sawi pada pembuatan pakan ternak berpotensi probiotik. Seminar Hasil Penelitian LPPM UNIMUS. Semarang (Indonesia): Universitas Muhammadiyah Semarang.

Winarno FG. 1997. Kimia pangan dan gizi. Jakarta (Indonesia): Gramedia Pustaka Utama.

Spranger T, Ottoboni M, Klootwijk C, Ovyn A, Deboosere S, De Meulenaer B, Michiles J, Eeckhout M, De Clerq P, De Smeta S. 2017. Nutritional composition of black soldier fly (Hermetia illucens) prepupae reared on different organic waste substrates. J Sci Food Agric. 97:2594-2600. 